\section{IJ§ER}

ISSN: 2149-5939
International Journal of Social Sciences and Education Research

Online, http://dergipark.gov.tr/ijsser

Volume: 3(1), 2017

\title{
What is the relationship between environmental quality, econom- ic growth and free trade?
}

\begin{abstract}
Aïcha El Alaoui ${ }^{1}$
Received Date: 28 / 08 / 2016

Accepted Date: 15 / 12 / 2016

Abstract

This paper tries to examine the links between free trade, growth, and environmental quality in Morocco, Algeria, Tunisia, and Egypt, denoted MATE. During the last years, many agreements are concluded especially with developed countries. These agreements can improve economic growth, which is necessary in response especially to the increasing demand of their populations, and to the improvement of the life's quality of their citizens. But, it can also decrease the environmental quality because there is a causal relationship between these variables. For that, quadratic and cubic functions for each country over the period 1970-2010 are tested to measure this relationship, and to determinate the possibilities of the existence of an inverted $U$-shaped or inverted $N$-shaped functions, and, then, a vector auto regression (VAR) or a vector error correction model (VECM) are used to analyze the long-run and short-run relationships between those variables. To complete analysis, it is often useful to know the response of independent variable and it adopts a variance decomposition to explain the magnitude of the forecast error variance determined by the stocks to each of the causal variables over time.
\end{abstract}

Keywords: Free trade, economic growth, environmental degradation, EKC, VECM/VAR, variance decomposition, impulse response function

JEL classification code: C32, F18, F43, N57

\section{Introduction}

The economic growth remains important for developing and developed countries. It affects people's well-being, such as health, education, employment and quality of life. It affects also government's stability, from social and nutritional security to political stability. The recent example of the case of Arabic countries is the "Jasmine" revolution started in Tunisia. The principal reasons behind this revolution are, especially, the high rate of unemployment, the high index of corruption, the poor living conditions, the lack of democracy (free election), and the deficiency of freedoms (freedom of the expression and press).

The economic growth is positively linked with, namely, foreign trade. Many studies are confirmed the existence of the long-run relationship between trade openness and economic growth (Michaely (1977); Balassa (1985, 1988); Ahmad and Kwan (1991); Demirhan and Akcay (2005); Wadad (2012); El Alaoui (2015)). However, this relationship can affects quality of the environment, which plays an important role in supporting all economic activities (agriculture, manufacturing and services). It contributes directly and indirectly in these activities. Directly by providing raw materials and minerals required as inputs for the production. Indirectly by providing ecosystems required as river, ocean and air.

\footnotetext{
${ }^{1}$ University of Sultan Moulay Slimane, Poly-disciplinary Faculty. Mghila, B.P. 592, CP: 23000, BeniMellal,
} Morocco.aicha_elalaoui@yahoo.fr 
El Alaoui, A. (2017). What is the relationship between environmental quality, economic growth and free trade? International Journal of Social Sciences and Education Research, 3(1), 124-144.

The environment is, therefore, vital for securing a sustainable economic growth and development, not only for the present but also for the future generation. It is defined by the Global Development Research Center as "the environment stock or resources of Earth that provide goods, flows and ecological services required to support life". This concept is used in many studies especially in this of Costanza and Daly (1992).

Since the industrial revolution, the environment has known many changes. These changes can be summarized in three aspects: the ozone layer, the temperature change, and the biodiversity loss (Daniel (1999); Chivian and Bernstein (2010); (Khagram, Clark and Raad (2003); Bass (2006); Martino and Zommers (2007), among others).

The environmental damage will be experienced, especially, by developing countries and the poorest people, such as in Sub-Saharian Africa, South Asia, Southeast Asia, and Latin America regions. In urban area, the risks for peoples, assets, economies and ecosystems have increased such as air pollution, drought and water scarcity (IPCC, 2014, p.15). In rural area, the major impacts are on water availability and supply, food security, infrastructure and agricultural incomes (IPCC, 2014, p.16). In fact, "the harmful effects of the degradation of the ecosystem services are being borne disproportionately by the poor, are contributing to the growing inequities and disparities across groups of people, and are sometimes the principal factor causing poverty and social conflict", (Bass, 2006).

Everybody has a clear conscience about environmental challenges, from averting dangerous climate changes to halting biodiversity losses and protecting our ecosystems. However, the developed economies have partially reduced the environmental damage by, especially, exporting/installing/relocating/transferring a part of their production as investments/goods/services in developing countries, thus exporting their pollution to these countries. But, these exchanges are important and vital for developing countries; it ensures continued economic growth and helps to reduce poverty, migration and unemployment. For that, the solution is in reducing environmental impacts namely by highlighting the importance of technological innovations in developing countries.

Study of the environment quality has been an important research topic in recent years, it has been considered to be one of the most important consequences of use of the natural resources. Thus, this work tries to examine the relationship between trade, economic growth and environment quality (measured by $\mathrm{CO} 2$ emissions per capita) in Morocco, Algeria, Tunisia, and Egypt, denoted MATE, where the main objective for these countries in the coming years is to improve economic growth in a context of economic opening, which is necessary in response to the increasing demand of their populations, the improvement of the life's quality of their citizens, and to meet the environmental challenges they face.

This paper is organized as follow: The second section reviews a sample of theoretical and empirical studies that focus on the relationships between opening, growth and environment. The third section presents economic and environmental situation in MATE. The fourth section is allotted for the presentation of the methodology and main results. The fifth section serves to conclude. 
El Alaoui, A. (2017). What is the relationship between environmental quality, economic growth and free trade? International Journal of Social Sciences and Education Research, 3(1), 124-144.

\section{Theoretical and empirical discussions}

The theoretical foundation of the relationship between trade openness and economic growth goes back to the founders of the classical theory. In fact, Smith and Ricardo were the first to identify the advantages that can be drawn by the countries to liberalize their trade. In the new world context, countries cannot live in autarchy. But, this situation has generated a strong pressure on the environment, El Alaoui (2015).

Grossman and Krueger (1991) analyzed the environmental impact of the North American Free Trade Agreement (NAFTA) distinguishing three separate mechanisms that can affect the level of pollution and the rate of depletion of scare environmental resources. These effects are the scale, the composition and the technique effects (Grossman and Krueger, 1991, pp. 3-4). Using a cubic function to estimate the concentration of pollutants in the air ${ }^{1}$, the authors found that $(i)$ trade liberalization generates some benefits such as increased income growth which tends to alleviate pollution problems and increased specialization in sectors that cause less than average amounts of environmental damage, and (ii) "the environmental impacts of trade liberalization in any country will depend not only upon the effect of policy change on the overall scale of the economic activity, but also upon the induced changes in the intersectoral composition of economic activity and in the technologies that are used to produce goods and services", p. 36. Thus, the main finding of Grossman and Krueger (1991) are called the Environmental Kuznets Curve, noted EKC, which refers to the hypothesis of an inverted U-shaped relationship between various indicators of environmental degradation and per capita income. The EKC takes the name of Simon Kuznets $(1955)^{2}$ who hypothesized that income inequality first rises and then falls as the economic development proceeds from a certain threshold's economic growth. In the EKC, degradation of the environment increase in the early stages of the economic growth, but beyond a certain level of per capita income, which will vary for different indicators, the trend reverses, so that a high income level of economic growth leads to environmental improvement. This implies that the environmental impact indicator is an inverted $\mathrm{U}$-shaped function of per capita income. Similar findings are reported by Grossman and Krueger (1995); Beckerman (1992); Shafik and Bandyopadhyay (1992); Panayotou (1993, 1997, 2003); Shafik (1994); Selden and Song (1994); and Cropper and Griffiths (1994) ${ }^{3}$.

Several studies have focused on relationship between international trade and environmental quality, and have confirmed that the international trade can improve the environmental quality. Accordingly, the international trade would accelerate income; so it can allow a quick passage to the ascending part of the curve. Grossman and Krueger (1991) showed that trade liberalization generates an increase in income levels, then it can strengthen the incentives for 'environmental dumping', p. 21. So they proposed that free trade can protect the environment. Lopez (1994) showed that "economic growth and

\footnotetext{
${ }^{1}$ The pollutants in the air is measured with SO2, suspended particles and dark matter (thin smoke)) in urban areas allowing to the Global Environmental Monitoring System (GEMS) dataset as part of a study of the potential environmental impacts of NAFTA.

${ }^{2}$ Simon Kuznets (1901-1985) was an American economist, demographer and statistician of Ukrainian origin. He won the Nobel Prize in 1971.

${ }^{3}$ For a chronological presentation of the EKC see Stern (2004). This author confirmed that the EKC concept was popularized through World Bank Development Report (1992).
} 
El Alaoui, A. (2017). What is the relationship between environmental quality, economic growth and free trade? International Journal of Social Sciences and Education Research, 3(1), 124-144.

trade liberalization decrease the degradation of natural resources if and only if producers internalize their stock feedback effects on production", p. 163. He concluded that the effect of trade liberalization depends on three assumptions: (i) the manufacturing sector is protected vis-à-vis to the primary sector, (ii) the productive stock effects of the resource occur entirely in the primary sector, and (iii) the productive sector is characterized by constant returns to scale technology, (Lopez, 1994, p. 183). Antweiler, Copeland and Taylor (2001) investigated how the openness to trading opportunities affects pollution concentrations by developing a theoretical model to divide trade's impact on pollution into scale, technique, and composition effects. The authors concluded that "free trade is good for the environment", p. 878.

The turning points ${ }^{1}$ come somewhere between $\$ 4,000$ and $\$ 5,000$ per capita GDP, measured in 1985 U.S. dollars, (Grossman and Krueger, 1991, p 5). 'Similar' results are found by Cropper and Griffiths (1992) which the turning points are $\$ 4,760$ per capita income for Africa and \$5,420 per capita income for Latin America. However, these points vary substantially across environmental indicators ${ }^{2}$. Shafik and Bandyopadhyay (1992) found that the turning points are $\$ 3,280, \$ 1,375$ and $\$ 1,375$ (per capita income in 1985 U.S. dollars) for sulfur dioxides, SPM and fecal coliform, respectively.

Other studies ${ }^{3}$ have estimated the turning point to be generally higher. The turning points vary for the different pollutants ${ }^{4}$, but almost in every case they occurred at an income of less than $\$ 8,000$ U.S dollars in 1985, (Grossman and Krueger, 1995, p. 369). Selden and Song's estimates are under $\$ 10,000$ per-head (1985 U.S dollars). These authors tested four indicators of air pollution ( $\mathrm{SPM}, \mathrm{SO}_{2}, \mathrm{NOx}$ and $\mathrm{CO}$ ) in their model. However, Cole, Rayner, and Bates (1997) used carbon dioxide, carbonated fluorocarbons (CFC) and halons, methane, nitrogen dioxide, sulfur dioxide, suspended particulates, carbon monoxide, nitrates, municipal waste, energy consumption and traffic volumes to examine the EKC. They have estimated the turning points for different pollutants (from a low $\$ 5,700$ to a high $\$ 34,700$ in 1985 U.S dollars).

The EKC has been the subject of growing criticism (Arrow et al. (1995); Ekins (1997); Torras and Boyce (1998); Perman and Stern (1999); Stern and Common (2001), and Cole and Neumayer (2005)). Some authors have confirmed that the EKC is just a utopia because the solution of environmental degradation is not related only to an economic growth and a higher income but there are several other factors can play an important role in improving our biodiversity and ecological systems such as education, quality of institution, and civil society ${ }^{5}$. Nevertheless, many critics have argued that the EKC suffers from severe methodological problems that cast doubt on the reliability of EKC results (Cole and Neumayer, 2005, p. 298). The authors documented that the

\footnotetext{
${ }^{1}$ Stern (2004) presented in table 1 (p. 1425) a summary of turning points for sulfur emissions and concentrations assigned at the several studies. See also table 1 of Cole (1999), p. 92.

${ }^{2}$ For more explication see Shafik (1994).

${ }^{3}$ See for example Selden and Song (1994), Grossman and Krueger (1995), and Cole, Rayner and Bates (1997).

${ }^{4}$ They focused on four types of indicators: concentrations of urban air pollution, measures of the state of the oxygen regime in river basins, concentrations of fecal contaminants in river basins, and concentrations of heavy metals in river basins.

${ }^{5}$ For example, Panayotou (1993) proposed that "the state of natural resources and the environment in a country depends on five main factors" ignoring/ neglecting other factors that impact economic growth. These factors are "(a) the level of economic activity or size of the economy; (b) the sectoral structure of the economy; (c) the vintage of technology; (d) the demand for environmental amenities; and (e) the conservation and environmental expenditures and their effectiveness", p. 2.
} 
El Alaoui, A. (2017). What is the relationship between environmental quality, economic growth and free trade? International Journal of Social Sciences and Education Research, 3(1), 124-144.

rich countries have become clean up, at least partly, by exporting the dirty production of products to poorer countries. This fact may therefore explain the reductions in local air pollution experienced in most developed countries found in many studies.

\section{Trade and environmental situation in MATE}

In MATE, economic growth differs significantly from a country to another and within the same country, Figure 1. The best growth rates of real GDP and of real GDP per capita were recorded during the period 1970-1989, and the highest rates were recorded in Egypt. However, Morocco grew speedily by 3.9\% during the period 2010 2013 against 3.1\%, 2.8\% and 2.6\% in Algeria, Egypt and Tunisia, respectively. These rates are lower than those recorded in Africa (all countries combined), South Asia, Sub-Saharan Africa (SSA), East Asia and Pacific (EAP) and China.

Figure 1. Averages growth of the Real GDP $(\mathrm{g})^{(1)}$ and of the Real GDP per capita $\left(\mathrm{g}_{\mathrm{y}}\right)^{(2)}$ in MATE and other regions of the World, in \%

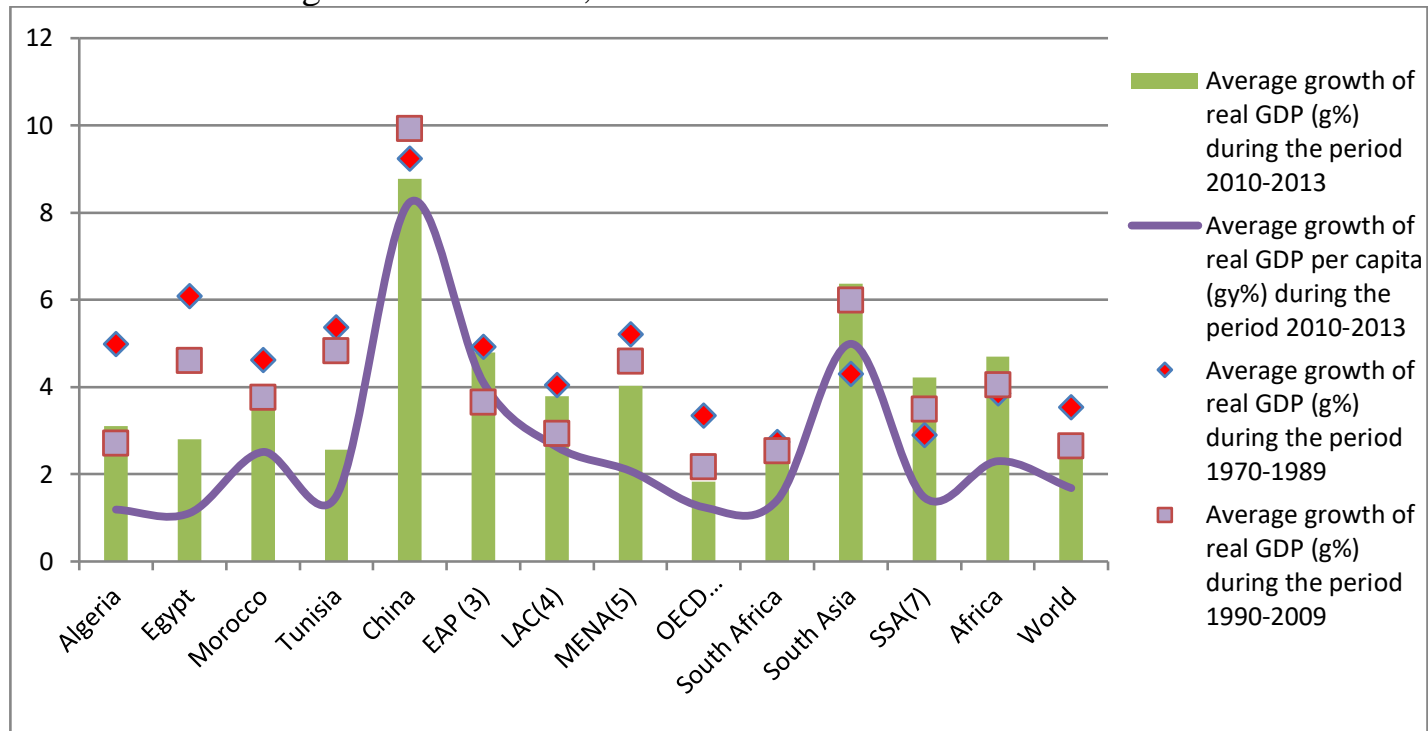

Source: Calculated using World Development Indicators (WDI), 2015. (1) $g$ is growth rate of the real GDP (2005 US\$); (2) $g_{y}$ is growth rate of the real GDP per capita [real GDP per capita =GDP (constant 2005 US\$)/total population]; (3) EAP is the East Asia and Pacific; (4) LAC is Latin America and Caribbean; (5) $M E N A$ is the Middle East and North Africa; (6) OECD is the Organization for Economic Co-operation and Development; (7) SSA is Sub-Saharan Africa.

These growths were accompanied by a rapid opening ${ }^{1}$ in all regions of the World, Table 1. The highest trades (\% of GDP) are recorded in Tunisia. Despite the highest average growths recorded in China (Figure 1), its trade (\% of GDP) is lower than that recorded in other regions of the world.

The GDP of developing countries are more depending to trade than developed countries. During 2000-2014, Tunisia's trade presents more than 96\%; it is higher than that recorded in Africa, which presents more than $80 \%$ of GDP. However, Algeria's, Egypt's and Morocco's trades are lower than that recorded in Africa; they are more than $66 \%, 50 \%$ and $72 \%$, respectively.

\footnotetext{
${ }^{1}$ The opening is the share of the sum of exports and imports of goods and services in gross domestic product (GDP).
} 
El Alaoui, A. (2017). What is the relationship between environmental quality, economic growth and free trade? International Journal of Social Sciences and Education Research, 3(1), 124-144.

Table 1. Trade's Averages in MATE and other regions of the World

\begin{tabular}{lcccc}
\hline & $\mathbf{1 9 8 0 - 1 9 8 9}$ & $\mathbf{1 9 9 0 - 1 9 9 9}$ & $\mathbf{2 0 0 0 - 2 0 0 9}$ & $\mathbf{2 0 0 0 - 2 0 1 4}$ \\
\hline Algeria & 50.1 & 50.1 & 67.2 & 66.7 \\
Egypt & 57.6 & 50.3 & 54.2 & 50.7 \\
Morocco & 54.7 & 52.6 & 68.5 & 72.6 \\
Tunisia & 80.0 & 86.5 & 92.5 & 96.5 \\
China & 19.6 & 34.1 & 52.1 & 50.1 \\
Africa & 71.5 & 71.0 & 81.2 & 81.1 \\
ESP & 39.4 & 42.5 & 56.8 & 58.4 \\
LAC & 32.7 & 38.5 & 47.7 & 48.4 \\
MENA & 69.6 & 64.2 & 79.6 & 82.4 \\
OECD members & 35.5 & 37.9 & 47.0 & 49.1 \\
SSA & 55.1 & 56.3 & 65.4 & 64.7 \\
World & 37.7 & 41.7 & 52.4 & 54.2 \\
\hline
\end{tabular}

Source: Calculated using WDI, 2015.

This situation is accelerated by application of many agreements especially since 2000. The annual growth of import is on its upward trend comparatively to the trend of the annual growth of export in MATE, Table 2.

Table 2. Shares' Averages of Exports and Imports in the Real GDP and annual growth (\%) of Exports and Imports in MATE by period

\begin{tabular}{cccccc} 
& Periods & Algeria & Egypt & Morocco & Tunisia \\
\hline & $1980-1989$ & 23.8 & 22.2 & 23.8 & 36.9 \\
\hline Exports of goods and & $1990-1999$ & 25.8 & 21.8 & 23.9 & 41.1 \\
services (\% of GDP) & $2000-2009$ & 41.8 & 25.1 & 31.0 & 44.9 \\
& $2010-2014$ & 35.6 & 18.5 & 33.8 & 48.1 \\
\hline & $1980-1989$ & 26.3 & 35.4 & 31.0 & 43.0 \\
\hline Imports of goods and & $1990-1999$ & 24.2 & 28.5 & 28.6 & 45.3 \\
services (\% of GDP) & $2000-2009$ & 25.4 & 29.1 & 37.5 & 47.6 \\
& $2010-2014$ & 30.2 & 25.2 & 47.1 & 56.4 \\
\hline \multirow{2}{*}{$\begin{array}{c}\text { Exports of goods and } \\
\text { services (annual \% }\end{array}$} & $1980-1989$ & 2.6 & 6.1 & 5.5 & 4.9 \\
growth) & $1990-1999$ & 2.9 & 4.3 & 6.5 & 5.0 \\
& $2000-2009$ & 2.2 & 13.1 & 5.3 & 7.9 \\
\hline Imports of goods and & $2010-2014$ & -2.4 & -2.1 & 6.7 & 5.1 \\
\hline services (annual \% & $1990-1999$ & -2.4 & -0.4 & 2.1 & 3.4 \\
\hline growth) & $2000-2009$ & 7.7 & 10.0 & 7.3 & 4.0 \\
& $2010-2014$ & 6.5 & 3.7 & 4.6 & 7.8 \\
\hline
\end{tabular}

Source: Calculated using WDI, 2015.

Figure 2 shows that, over the period 2000-2014, the share of imports in real GDP is higher than that of exports in Egypt, Morocco and Tunisia with similar annual growth of imports and exports between $6 \%$ and $8 \%$. However, the share of exports in real GDP is higher than that of imports in Algeria, but the annual growth of exports (7.3\%) is more important than that of imports $(0.7 \%)$. This situation can be explained by the structure of trade. 
El Alaoui, A. (2017). What is the relationship between environmental quality, economic growth and free trade? International Journal of Social Sciences and Education Research, 3(1), 124-144.

Figure 2. Averages Share of Exports and Imports in the Real GDP and annual growth (\%) of Exports and Imports in MATE over the period 2000-2014

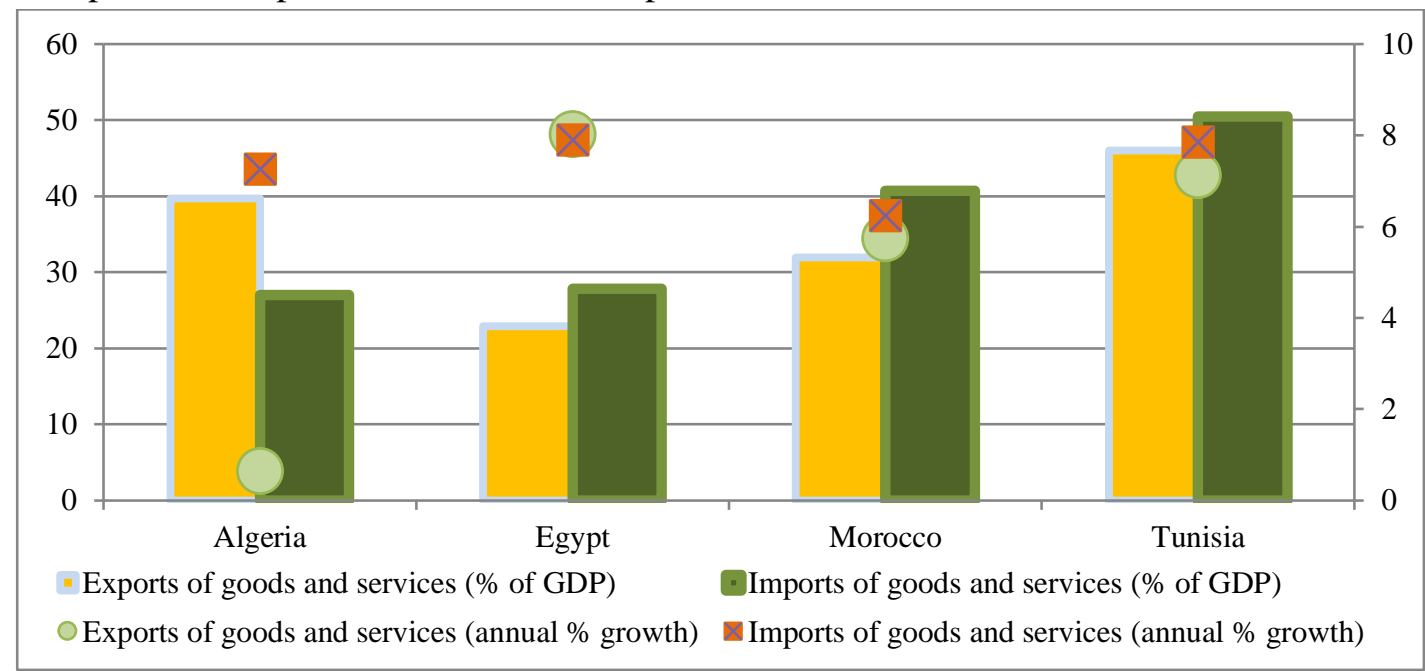

Source: Elaborated using WDI, 2015.

The structure of trade in MATE is characterized by the highest share of the merchandise and the lowest export and import of information and communication technology goods (ICT) in GDP. There is a considerable divergence in this structure between MATE. The majority of the energy used in Morocco is imported. It represents more than $89 \%$ of total of the energy imports against only more than $18 \%$ in Tunisia. However, shares of the energy imported by Egypt and Algeria are negative because these countries are the exporters of these energies.

Table 3. Structure of Trade in MATE during the period 2000-2014, in \%

\begin{tabular}{lcccc}
\hline & Algeria & Egypt & $\begin{array}{c}\text { Moroc- } \\
\text { co }\end{array}$ & Tunisia \\
\hline Trade (\% of GDP) & 66.7 & 50.7 & 72.6 & 96.5 \\
Trade in services (\% of GDP) & 7.9 & 19.8 & 23.4 & 18.5 \\
Merchandise trade (\% of GDP) & 59.6 & 33.2 & 56.4 & 80.7 \\
Exports of goods and services (\% of GDP) & 39.7 & 22.9 & 31.9 & 46.0 \\
Imports of goods and services (\% of GDP) & 27.0 & 27.8 & 40.7 & 50.5 \\
Energy imports, net (\% of energy use) & -348.1 & -20.9 & 89.4 & 18.2 \\
ICT goods exports (\% of total goods exports) & 0.0034 & 0.17 & 5.08 & 3.60 \\
ICT goods imports (\% total goods imports) & 4.8 & 3.9 & 6.1 & 5.0 \\
Manufactures exports (\% of merchandise exports) & 2.1 & 36.4 & 66.1 & 75.4 \\
Manufactures imports (\% of merchandise imports) & 72.9 & 52.8 & 61.1 & 71.7 \\
Fuel exports (\% of merchandise exports) & 97.2 & 38.6 & 2.7 & 13.2 \\
Fuel imports (\% of merchandise imports) & 2.6 & 11.4 & 20.9 & 13.1 \\
Food exports (\% of merchandise exports) & 0.3 & 11.7 & 19.8 & 9.2 \\
Food imports (\% of merchandise imports) & 21.2 & 21.6 & 11.9 & 9.3 \\
\hline
\end{tabular}

Source: Calculated using WDI, 2015.

The trade has an important share in GDP. Consequently, it has an important impact on economic activities. It can boost demand for transport and production, telecommunication technology, manufactured goods .... So, it can indirectly affect styles' life of citizens through the transformation in the population's behavior. The citizens can consume many goods with the best price in the market. Thus, these pressures will increase 
El Alaoui, A. (2017). What is the relationship between environmental quality, economic growth and free trade? International Journal of Social Sciences and Education Research, 3(1), 124-144.

the environmental damage especially in the air and water. In this study, the environmental damage is measured by $\mathrm{CO} 2$ emissions per capita.

El Alaoui and Nekrache (2015) found that (i) Africa's emissions are lower compared to those of the World; (ii) the highest $\mathrm{CO} 2$ emissions per GDP are recorded in China and EAP-developing countries; (iii) $\mathrm{CO} 2$ emissions per capita are recorded in OECD members followed by South Africa; (iv) Egypt's emissions per GDP are more important than those recorded in Algeria, Morocco and Tunisia, and those recorded in MENA; (v) Algeria's emissions per capita are higher than those recorded in Egypt, Morocco and Tunisia, but lower than those recorded in MENA; (vi) MATE's emissions per GDP are higher than those recorded in Africa and the World, but MATE's emissions per capita are lower than those recorded in the World and more important than those recorded in Africa.

\section{Methodology and results}

\section{4-1. Examination of application of EKC curve}

In the first step, we estimate a quadratic function for each country over the period 1970-2010 ${ }^{1}$ to check the existence of inverted U-shaped function. Then, we estimate a cubic function in the second step to check if $\mathrm{N}$-shaped function can explain the relationship between GDP, trade and CO2 emissions. This form is found by many authors namely Torras and Boyce (1998), List and Gallet (1999) and Bradford et al. (2005). Therefore, two functions are applied and they are presented as follows.

A quadratic function: this function is applied to determinate the existence of an EKC, i.e. the determination of the environmental curve in the form of an inverted $U$, (Figure 3.a). It is specified by the following form.

$L C O 2 Y_{i t}=a_{0}+a_{1} L Y_{i t}+a_{2}\left(L Y_{i t}\right)^{2}+b_{1} O_{\text {OPEN }}+b_{2}\left(O P E N_{i t}\right)^{2}+c_{1} U_{i t}+\varepsilon_{t}$

For each $\mathrm{i}=$ Algeria, Egypt, Morocco or Tunisia.

$t=' 1970,1981 \ldots 2010$ ' year

A cubic function is applied to verify the existence of the $\mathrm{N}$-form of the EKC, (Figure 3.b). This function is presented as follows.

$L C O 2 Y_{i t}=b_{0}+a_{1} L Y_{i t}+a_{2}\left(L Y_{i t}\right)^{2}+a_{3}\left(L Y_{i t}\right)^{3}+b_{1}$ OPEN $_{i t}+b_{2}\left(O P E N_{i t}\right)^{2}+c_{1} U_{i t}+\varepsilon_{t}$

For each i= Algeria, Egypt, Morocco or Tunisia.

$t=' 1970,1981 \ldots 2010$ ' year

Here, $L C O 2 Y$ is the logarithm of the environmental degradation measured by $\mathrm{CO} 2$ emission per capita, $L Y$ is the logarithm of the per capita income, $L O P E N$ is an indicator that measure the degree of openness which equal at $(X+M) / G D P(X$ and $M$ represent, respectively, exportation and importation), and $U$ presents the urbanization rate because more people especially in cities involve more wastes and consumption of carburant and combustible. The term $\varepsilon_{t}$ is referred to the error term.

\footnotetext{
${ }^{1}$ Data of CO2 emissions per capita is not available over the period 2011-2015.
} 
El Alaoui, A. (2017). What is the relationship between environmental quality, economic growth and free trade? International Journal of Social Sciences and Education Research, 3(1), 124-144.

To verify the existence of EKC in equation 1, it implies that the coefficients $a_{1}$ and $a_{2}$ will be positive and negative, respectively, $\left(a_{1}>0\right.$ and $\left.a_{2}<0\right)$. In that case, there is a level of real GDP per capita beyond which the environmental indicator begins to improve, the turning point (noted $Y_{t p}$ ) which it is determined by: $Y_{t p}=\exp \left(-\frac{a_{1}}{2 a_{2}}\right)$. To test the $\mathrm{N}$-shaped curve, $a_{3}$ in equation 2 will be positive $\left(a_{3}>0\right)$.

Figure 3. Relationship between real GDP per capita (LY) and the environmental quality (LCO2Y)

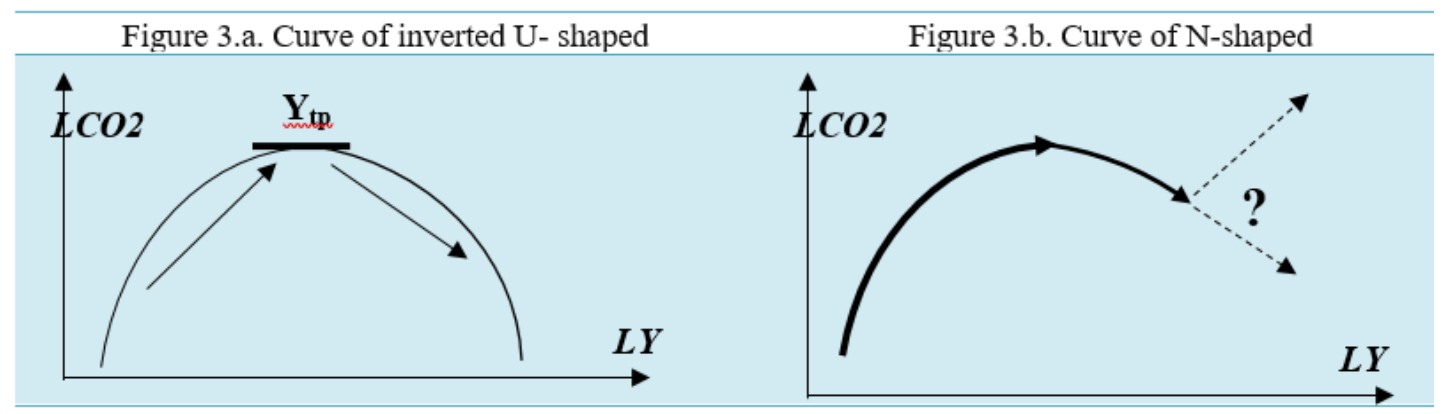

Investigation of the relationship between trade (measured by the degree of openness) and environmental quality is motivated by the fact that the trade can increase real income. The environment is considered as luxury and not it is an important good for economic activities and life. So, the increased income from free trade encourages country to scarify à part of its income to protect the environment (Galeotti and Lanza, 1999). The idea behind this relationship is simple. Enrichment of population or country was accompanied by the demand for a cleaner environment. The main preoccupations, normally, for a poor country is to afford the basic necessities for their citizens, leaving any place for other concerns as environmental issues because the income is lower, but when a country becomes rich, it can scarify à part of its income to other concerns as to protect the environment. Consequently, a country tends to follow increasing pollution levels as trade openness proceeds $\left(b_{1}>0\right)$, and then we can find declining pollution levels at more advanced stage of free trade $\left(b_{2}<0\right)$.

Table 4 summarizes the regression results for each country based on the two models mentioned above (equation 1 and equation 2). 
El Alaoui, A. (2017). What is the relationship between environmental quality, economic growth and free trade? International Journal of Social Sciences and Education Research, 3(1), 124-144.

Table 4. Results of equations 1 and 2 from OLS estimation method, sample 1970: 2010

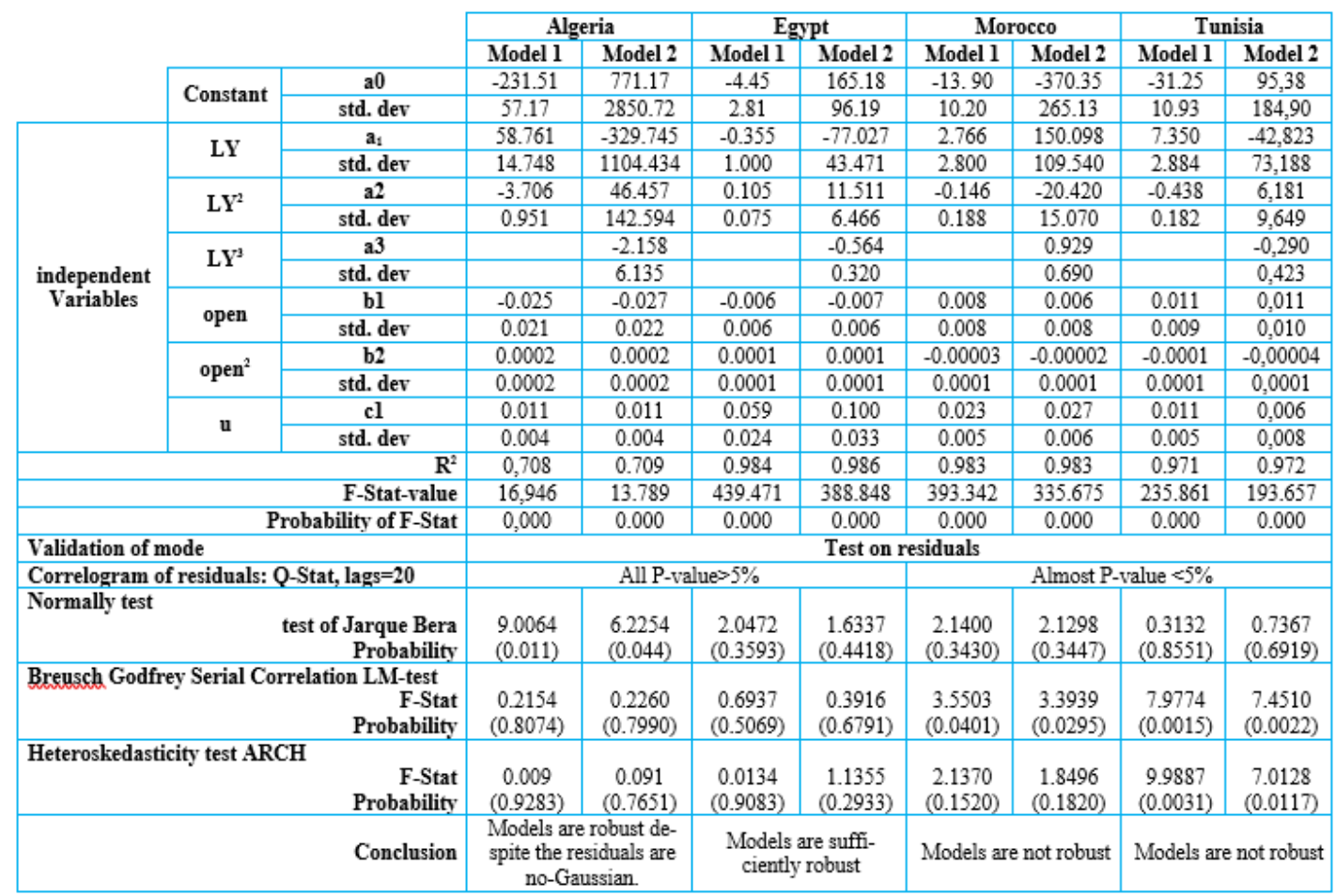

Source: Estimated using the available data.

In model 1, the real GDP per capita and its square are expected signs in Algeria's $\left(a_{1}>0\right.$ and $\left.a_{2}<0\right)$. These results can suggest that estimates of the EKC are adequate models. However, the results in cases of Morocco and Tunisia can suggest that estimates of the EKC are inadequate models despite that the coefficients attached to real GDP per capita are expected signs. These results concur with deduction of Stern (2004) which suggested that " the majority of studies have found the EKC to be a fragile model suffering from severe econometric misspecification", p. 1431.

In model 2, real GDP per capita in case of Morocco, its square and its cubic have expected signs but the residuals are not normally distributed (no-Gaussian). In cases of Algeria and Tunisia, the coefficients attached to these explanatory variables have not expected sings and also the residuals are not stationary and non-normally distributed. So, these variables cannot exhibit $\mathrm{N}$-shaped relationships with $\mathrm{CO} 2$ emissions per capita. Similarly, the coefficients attached to open are not expected signs. So, the trade cannot exhibit inverted U-shaped relationship with environmental quality.

In both models, Egypt is a particular case. The models are good models but the coefficients attached to real GDP per capita, its square and its cubic are not expected signs. Therefore, we cannot conclude that there is an inverted $\mathrm{U}$-shaped function or an inverted $\mathrm{N}$-shaped function with $\mathrm{CO} 2$ emissions per capita. The coefficients attached to open and its square have a negative and positive signs, respectively. So, these results can expect a $\mathrm{U}$-shaped curve between trade and $\mathrm{CO} 2$ emissions per capita (Figure 4). The turning points are between $52 \%$ and $55 \%$ as indicator of openness. This point is determined by: Open $_{t p}=-\frac{b_{1}}{2 b_{2}}$ 
El Alaoui, A. (2017). What is the relationship between environmental quality, economic growth and free trade? International Journal of Social Sciences and Education Research, 3(1), 124-144.

Figure 4. Relationship between trade (open) and the environmental quality (LCO2Y) in case of Egypt

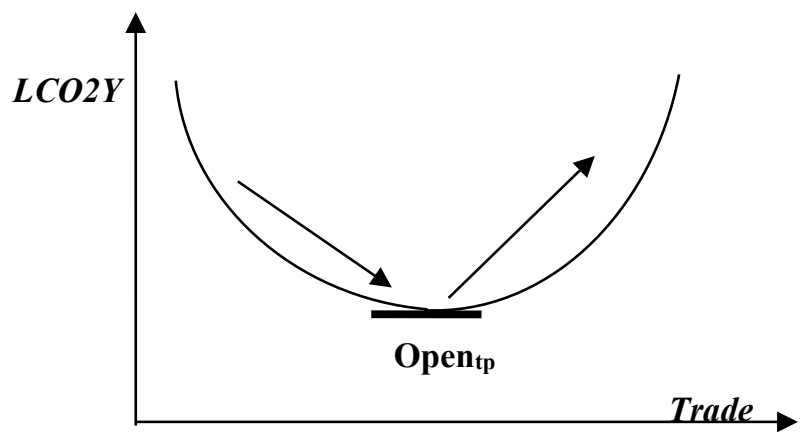

The urbanization rate is linked positively and significantly to $\mathrm{CO} 2$ emissions per capita in both models in case of Egypt. This result means that the urbanization increases the environmental damage.

\section{4-2. The VECM or VAR model}

To define the kind of relationship between environmental quality, economic growth and trade, it is useful to test a long-run relationship using the VECM. This model involves three important steps. The first step studies the stationarity of these variables using ADF test. If the variables are non-stationary and integrated of the same ordered. Then, it is possible to move to the second step. This step uses Johansen's test to check possibility of the existence of a long-term stable relationship among these variables. To complete this analysis, it is important to study the sense of their causality with the Granger test. The third step depends on the results of the second step. If there is a relation of cointegration between the dependent and explanatory variables, then it is able to deduct the existence of a long-run dynamic relationship between these variables. But, if these variables are not cointegrated, then it is not able to deduct the existence of a long-run dynamic relationship between among variables. In this case, it is possible to check only the existence of a short-run relationship between these variables. In this case, the VAR model is applied. Therefore, under such conditions, two models will be applied for each country of MATE:

(i) If all variables are non-stationary (and interested with same order) and cointegrating vector exists, the VECM can be used as follows.

The long-run equation is:

$$
L C O 2 Y_{t}=a_{0}+a_{1} L Y_{t}+a_{2} \text { Open }_{t}+\varepsilon_{t}
$$

The short-run equation is:

$$
\Delta L C O 2 Y_{t}=\alpha_{0}+\sum_{i=1}^{p} \alpha_{1 i} \Delta L Y_{t-i}+\sum_{i=1}^{p} \alpha_{2 i} \text { Open }_{t-i}+U_{t}+\alpha_{4} E C M_{t-1}+\varepsilon_{1 t}
$$

Where, $\Delta$ represents the difference operator. The symbol of $\mathrm{p}$ is the number of lags. $\varepsilon_{\mathrm{t}}$ presents the stochastic error term with mean zero and a constant variance. $\mathrm{ECM}_{\mathrm{t}-1}$ referred to the error correction term (ECT) derived from the long-run relationship. 
El Alaoui, A. (2017). What is the relationship between environmental quality, economic growth and free trade? International Journal of Social Sciences and Education Research, 3(1), 124-144.

(ii) If the variables are non-stationary $\mathrm{I}(\mathrm{d})$ and not cointegrated, the Vector autoregression (VAR) model in the $\mathrm{d}^{\text {th }}$ difference form and without the ECM can be used and estimated.

To ensure proper specification of this model, it is necessary to determine the optimum lags lengths ( $p$ ), which are determined using five criterions: the Sequential modified LR test, the Final Prediction Error (FPE), the Akaike Information Criterion (AIC), the Schwarz Information Criterion (SC), and the Hannan-Quinn information criterion (HQ). The results show that the optimal lag order length is $\mathrm{p}=1$ in Algeria, Egypt and Morocco, and $\mathrm{p}=2$ in Tunisia.

Table 5 shows that all variables of MATE are stationary in the first difference, i.e. they are integrated of order one I(1). This result suggests a stable long-run relationship between these variables.

Table 5. Stochastic properties of variables, annually series

\begin{tabular}{|c|c|c|c|c|c|c|c|c|}
\cline { 2 - 9 } \multicolumn{1}{c|}{} & \multicolumn{2}{c|}{ Algeria } & \multicolumn{2}{c|}{ Egypt } & \multicolumn{2}{c|}{ Morocco } & \multicolumn{2}{c|}{ Tunisia } \\
\cline { 2 - 9 } \multicolumn{1}{c|}{} & \multicolumn{2}{c|}{ Variables in } & \multicolumn{2}{c|}{ Variables in } & \multicolumn{2}{c|}{ Variables in } & \multicolumn{2}{c|}{ Variables in } \\
\cline { 2 - 9 } & level & $\begin{array}{c}\text { first dif- } \\
\text { ference }\end{array}$ & level & $\begin{array}{c}\text { first differ- } \\
\text { ence }\end{array}$ & level & $\begin{array}{c}\text { first differ- } \\
\text { ence }\end{array}$ & level & $\begin{array}{c}\text { first differ- } \\
\text { ence }\end{array}$ \\
\hline \multirow{2}{*}{ CO2Y } & $0.307 *$ & -7.441 & -2.518 & -2.518 & -1.629 & -5.738 & -2.923 & -7.267 \\
\cline { 2 - 9 } & $(-1.950)$ & $(-1.950)$ & $(-3.527)$ & $(-3.527)$ & $(-2.941)$ & $(-2.941)$ & $(-3.527)$ & $(-2.939)$ \\
\hline \multirow{2}{*}{ LY } & -2.468 & -8.775 & -0.686 & -3.643 & 0.528 & -10.354 & -1.087 & -6.431 \\
\cline { 2 - 9 } & $(-2.960)$ & $(-2.939)$ & $(-2.937)$ & $(-2.939)$ & $(-2.939)$ & $(-2.939)$ & $(-2.937)$ & $(-2.939)$ \\
\hline \multirow{2}{*}{ OPEN } & -1.529 & -4.765 & -2.431 & -5.454 & -1.548 & -8.128 & -1.944 & -6.097 \\
\cline { 2 - 9 } & $(-2.937)$ & $(-2.939)$ & $(-2.937)$ & $(-2.939)$ & $(-2.939)$ & $(-2.939)$ & $(-2.937)$ & $(-2.939)$ \\
\hline
\end{tabular}

Notes: * indicates the ADF statistic and in ( ) is Critical values of the $\mathrm{ADF}$ statistic at $5 \%$ level

The results of the Johansen cointegration test imply a long-run relationship between among CO2Y, LY, and OPEN in cases of Algeria and Tunisia, and a long-run association no-exist among these variables in cases of Egypt and Morocco. These results are reported in Table 6.

Table 6. Results of the Johansen Cointegration Test

\begin{tabular}{|c|c|c|c|c|c|c|c|c|}
\hline \multirow{2}{*}{ Ho } & \multirow{2}{*}{ Eigenvalue } & \multicolumn{3}{|c|}{ Max-Eigen } & \multicolumn{3}{|c|}{ Trace } & \multirow{2}{*}{ Conclusion } \\
\hline & & Statistic & $C V$ at $5 \%^{(2)}$ & Prob. ${ }^{(3)}$ & Statistic & $\mathrm{CV}$ at $5 \%$ & Prob. & \\
\hline \multicolumn{9}{|c|}{ Algeria } \\
\hline$r=0^{(1)}$ & 0.752 & 54.380 & 21.132 & 0.000 & 72.015 & 29.797 & 0.000 & \multirow{3}{*}{$\begin{array}{l}1 \text { cointegra- } \\
\text { tion }\end{array}$} \\
\hline $\mathbf{r}=1$ & 0.306 & 14.262 & 14.265 & 0.050 & 17.635 & 15.495 & 0.024 & \\
\hline$r=2$ & 0.083 & 3.373 & 3.841 & 0.066 & 3.373 & 3.841 & 0.066 & \\
\hline \multicolumn{9}{|c|}{ Egypt } \\
\hline $\mathbf{r}=\mathbf{0}$ & 0.362 & 17.517 & 22.300 & 0.204 & 30.934 & 35.193 & 0.134 & \multirow{3}{*}{$\begin{array}{l}\text { no cointe- } \\
\text { gration }\end{array}$} \\
\hline $\mathbf{r}=\mathbf{1}$ & 0.235 & 10.433 & 15.892 & 0.297 & 13.416 & 20.262 & 0.332 & \\
\hline $\mathbf{r}=2$ & 0.074 & 2.983 & 9.165 & 0.584 & 2.983 & 9.165 & 0.584 & \\
\hline \multicolumn{9}{|c|}{ Morocco } \\
\hline $\mathbf{r}=\mathbf{0}$ & 0.362 & 17.546 & 21.132 & 0.148 & 27.537 & 29.797 & 0.089 & \multirow{3}{*}{$\begin{array}{l}\text { no cointe- } \\
\text { gration }\end{array}$} \\
\hline $\mathrm{r}=1$ & 0.224 & 9.868 & 14.265 & 0.221 & 9.991 & 15.495 & 0.281 & \\
\hline$r=2$ & 0.003 & 0.124 & 3.841 & 0.725 & 0.124 & 3.841 & 0.725 & \\
\hline \multicolumn{9}{|c|}{ Tunisia } \\
\hline$r=0$ & 0.479 & 24.800 & 21.132 & 0.015 & 38.832 & 29.797 & 0.004 & \multirow{3}{*}{$\begin{array}{l}1 \text { cointegra- } \\
\text { tion }\end{array}$} \\
\hline $\mathbf{r}=\mathbf{1}$ & 0.285 & 12.732 & 14.265 & 0.086 & 14.032 & 15.495 & 0.082 & \\
\hline$r=2$ & 0.034 & 1.299 & 3.841 & 0.254 & 1.299 & 3.841 & 0.254 & \\
\hline
\end{tabular}

Notes: (1) $\mathrm{r}$ is the number of the hypothesized cointegrating relationships. (2) MacKinnon-HaugMichelis (1999) p-values. (3) Probability at 0.05 level. 
El Alaoui, A. (2017). What is the relationship between environmental quality, economic growth and free trade? International Journal of Social Sciences and Education Research, 3(1), 124-144.

With respect to optimal lag order length, results of the cointegration test can be concluded as the long-run equilibrium between variables in cases of Algeria and Tunisia which are:

$$
\begin{aligned}
& L C O 2 Y_{-} A \lg =2.6654-0.2124 L Y \_A \lg +0.0004 \text { Open_Alg }_{-} \\
& L C O 2 Y_{-} \text {Tun }=-2.9795+0.4197 \text { LY_Tun+0.0031 Open_Tun }
\end{aligned}
$$

Note:_Alg is index of Algeria and _Tun is index of Tunisia

We note that the VECM is validated if the coefficient attached to the error correction term (ECT) is negative and statistically significant. This term measures speed of adjustment in the long-run. In Algeria's case, ECT is negative and statistically significant. The size of coefficients of the ECT is $53.4 \%$. In the same way, the coefficient ECT in Tunisia's case is negative and statistically significant meaning that the environmental quality is balanced in the long-run by $47.02 \%$.

The VECM of Algeria and Tunisia not only take into consideration the impact of the long-term factors on the explication of the deviation of dependent variable but it also allows examination of the short-run impacts factors. Table 7 shows these results.

\begin{tabular}{|c|c|c|c|c|c|c|}
\hline & $\mathrm{D}(\mathrm{CO} 2 \mathrm{Y})$ & $\mathbf{D}(\mathbf{L Y})$ & D(OPEN) & $\mathrm{D}(\mathrm{CO} 2 \mathrm{Y})$ & $\mathbf{D}(\mathbf{L Y})$ & D(OPEN) \\
\hline & \multicolumn{3}{|c|}{ Algeria } & \multicolumn{3}{|c|}{ Tunisia } \\
\hline \multirow[t]{2}{*}{ ECT } & $-0.5344^{*}$ & $-0.1641^{*}$ & -2.3538 & $-0.4702^{*}$ & $-0.2621^{*}$ & -14.9678 \\
\hline & $(0.1148)$ & $(0.0219)$ & $(5.0155)$ & $(0.1532)$ & $(0.0624)$ & $(25.096)$ \\
\hline \multirow[t]{2}{*}{$\mathrm{D}(\mathrm{CO} 2 \mathrm{Y}(-1))$} & -0.1770 & $0.0933^{*}$ & $10.7571^{* *}$ & 0.0121 & $0.3828 *$ & 22.8205 \\
\hline & $(0.1345)$ & $(0.0257)$ & $(5.8787)$ & $(0.2020)$ & $(0.0822)$ & (33.076) \\
\hline \multirow[t]{2}{*}{$\mathrm{D}(\mathrm{CO} 2 \mathrm{Y}(-2))$} & & & & 0.2727 & $0.2272 *$ & 11.8144 \\
\hline & & & & $(0.1995)$ & $(0.0812)$ & $(32.669)$ \\
\hline \multirow[t]{2}{*}{$\mathbf{D}(\mathbf{L Y}(-1))$} & 0.2507 & $-0.2701^{*}$ & 10.0633 & -0.4815 & $-0.6428^{*}$ & -34.9706 \\
\hline & $(0.4466)$ & $(0.0853)$ & $(19.5180)$ & $(0.3436)$ & $(0.1398)$ & $(56.280)$ \\
\hline \multirow[t]{2}{*}{$\mathbf{D}(\mathbf{L Y}(-2))$} & & & & -0.4239 & $-0.2885^{*}$ & 12.5132 \\
\hline & & & & $(0.2993)$ & $(0.1218)$ & $(49.018)$ \\
\hline \multirow[t]{2}{*}{ D (OPEN (-1)) } & $-0.0083^{*}$ & 0.0005 & $0.2913 * *$ & -0.0018 & $-0.0009^{*}$ & -0.0683 \\
\hline & $(0.0037)$ & $(0.0007)$ & $(0.1629)$ & $(0.0012)$ & $(0.0005)$ & $(0.2020)$ \\
\hline \multirow[t]{2}{*}{ D (JOPEN (-2)) } & & & & -0.0019 & -0.0005 & -0.2277 \\
\hline & & & & $(0.0015)$ & $(0.0006)$ & $(0.2428)$ \\
\hline \multirow[t]{2}{*}{$\mathbf{C}$} & -0.2515 & $-0.0809^{*}$ & -4.3057 & $-0.3768^{*}$ & $-0.3517^{*}$ & -14.1116 \\
\hline & $(0.1690)$ & $(0.0323)$ & $(7.3871)$ & $(0.1959)$ & $(0.0797)$ & (32.0840) \\
\hline \multirow[t]{2}{*}{$\mathbf{U}$} & $0.0054^{* *}$ & $0.0018^{*}$ & 0.0817 & $0.0074^{*}$ & $0.0068^{*}$ & 0.2716 \\
\hline & $(0.0032)$ & $(0.0006)$ & $(0.1379)$ & $(0.0035)$ & $(0.0014)$ & $(0.5691)$ \\
\hline
\end{tabular}

Table 7. Results of VECM estimates applied in cases of Algeria and Tunisia

Notes: Standard errors in ( ). * Significant at 5\% level.** Significant at $10 \%$ level. ECT is the error correction term.

To insure the directional causality between among these variables, the Granger causality test is used, Table 8 . The results show that two ways directional causality exist from real GDP per capita and open to $\mathrm{CO} 2$ emissions per capita in case of Algeria and from $\mathrm{CO} 2$ emissions per capita and open to real GDP per capita in case of Tunisia.

All these results show that:

In Algeria's case, the coefficient of the real GDP per capita is not significant, meaning that the real GDP per capita cannot affect $\mathrm{CO} 2$ emissions per capita in the 
El Alaoui, A. (2017). What is the relationship between environmental quality, economic growth and free trade? International Journal of Social Sciences and Education Research, 3(1), 124-144.

short period. In addition, the coefficient of OPEN is significant at 5\% and its sign is negative. Therefore, trade is found to have a negative short-run relationship with $\mathrm{CO} 2$ emissions per capita. If the degree of openness (open) increases by $1 \%$, then $\mathrm{CO} 2$ emissions per capita decreases by only $0.8 \%$.

In Tunisia's case, the coefficients of the real GDP per capita and open cannot affect $\mathrm{CO} 2$ emissions per capita in the short period.

The coefficient of exogenous variable (the urbanization rate, $U$ ) is significant and its sign is positive. This positive relation varies from 0.0018 to 0.0068 .

Table 8. Granger Causality-Wald statistics

\begin{tabular}{|c|c|c|c|c|c|c|c|}
\hline & \multicolumn{3}{|c|}{ Algeria } & \multicolumn{3}{|c|}{ Tunisia } & \\
\hline & \multicolumn{6}{|c|}{ Dependent variable: } & \\
\hline & $\mathrm{D}(\mathrm{LCO} 2 \mathrm{Y})$ & $\mathbf{D}(\mathbf{L Y})$ & D(OPEN) & D(LCO2Y) & $\mathbf{D}(\mathbf{L Y})$ & D(OPEN) & \\
\hline \multirow[t]{2}{*}{$\mathrm{D}(\mathrm{LCO} 2 \mathrm{Y})$} & & 13.171 & 3.348 & \multicolumn{3}{|c|}{21.881} & $\chi^{2}$ statistics \\
\hline & \multicolumn{3}{|c|}{0.000} & \multicolumn{3}{|c|}{0.000} & Prob. \\
\hline \multirow[t]{2}{*}{$\mathbf{D}(\mathbf{L Y})$} & 0.315 & & 0.266 & 2.802 & & 0.476 & $\chi^{2}$ statistics \\
\hline & 0.575 & & 0.606 & 0.246 & & 0.788 & Prob. \\
\hline \multirow[t]{2}{*}{ D(OPEN) } & 4.923 & 0.507 & & 3.700 & 3.592 & 0.706 & $\chi^{2}$ statistics \\
\hline & 0.027 & 0.476 & & 0.157 & 0.166 & 0.703 & Prob. \\
\hline \multirow[t]{4}{*}{ All } & 4.983 & 13.171 & 4.166 & 4.767 & 21.955 & 1.036 & $\chi^{2}$ statistics \\
\hline & 0.083 & 0.001 & 0.125 & 0.312 & 0.000 & 0.904 & Prob. \\
\hline & \multicolumn{3}{|c|}{ Egypt } & \multicolumn{3}{|c|}{ Morocco } & \\
\hline & $\mathrm{LCO} 2 \mathrm{Y}$ & LY & OPEN & $\mathrm{LCO} 2 \mathrm{Y}$ & LY & OPEN & \\
\hline \multirow[t]{2}{*}{ LCO2Y } & & 11.079 & 0.655 & & 0.008 & 2.347 & $\chi^{2}$ statistics \\
\hline & & 0.001 & 0.418 & & 0.927 & 0.126 & Prob. \\
\hline \multirow[t]{2}{*}{$\mathbf{L Y}$} & 7.106 & & 0.515 & 6.666 & & 0.888 & $\chi^{2}$ statistics \\
\hline & 0.008 & & 0.473 & 0.010 & & 0.346 & Prob. \\
\hline \multirow[t]{2}{*}{ OPEN } & 1.941 & 13.130 & & 0.002 & 15.608 & & $\chi^{2}$ statistics \\
\hline & 0.164 & 0.000 & & 0.963 & 0.000 & & Prob. \\
\hline \multirow[t]{2}{*}{ All } & 9.361 & 24.048 & 1.062 & 6.927 & 18.261 & 6.665 & $\chi^{2}$ statistics \\
\hline & 0.009 & 0.000 & 0.588 & 0.031 & 0.000 & 0.036 & Prob. \\
\hline
\end{tabular}

As mentioned above, there are not a cointegrating equation in cases of Egypt and Morocco. So, the VAR are used in these cases, Table 9. Using Pairwise Granger causality test, Table 8, the results show that (1) open and GDP can jointly influence at 5\% dependent variable (CO2 emissions per capita) in cases of Egypt and Morocco; (2) open cannot individually influence $\mathrm{CO} 2$ emissions per capita; (3) open and $\mathrm{CO} 2$ emissions can jointly influence real GDP per capita in case of Egypt; and (4) real GDP per capita and $\mathrm{CO} 2$ emissions per capita cannot jointly influence trade. 
El Alaoui, A. (2017). What is the relationship between environmental quality, economic growth and free trade? International Journal of Social Sciences and Education Research, 3(1), 124-144.

Table 9. Vector Autoregression estimates

\begin{tabular}{|c|c|c|c|c|c|c|}
\hline & \multicolumn{4}{|c|}{ Egypt } & \multicolumn{2}{|l|}{ Morocco } \\
\hline & \multicolumn{6}{|c|}{ Dependent variable: } \\
\hline & LCO2Y & $\mathbf{L Y}$ & OPEN & LCO2Y & LY & OPEN \\
\hline \multirow[t]{2}{*}{$\operatorname{LCO} 2 Y(-1)$} & $0.458^{*}$ & $0.208^{*}$ & -19.707 & $0.521^{*}$ & -0.010 & 25.942 \\
\hline & [ 2.433] & [3.329] & {$[-0.810]$} & [3.469] & {$[-0.091]$} & {$[1.532]$} \\
\hline \multirow{2}{*}{ LY (-1) } & $0.532 *$ & $0.769^{*}$ & 18.514 & $0.394 *$ & $0.683^{*}$ & 16.213 \\
\hline & {$[2.666]$} & [ 11.612$]$ & {$[0.717]$} & {$[2.582]$} & [5.861] & {$[0.942]$} \\
\hline \multirow[t]{2}{*}{ OPEN (-1) } & 0.001 & $0.001^{*}$ & $0.696^{*}$ & 0.000 & $0.004^{*}$ & $0.332 *$ \\
\hline & [1.393] & [3.623] & [5.621] & {$[0.047]$} & [3.951] & {$[2.036]$} \\
\hline \multirow[t]{2}{*}{$\mathbf{C}$} & $-3.830^{*}$ & $1.849^{*}$ & -279.564 & $-3.342 *$ & $1.819^{*}$ & -30.573 \\
\hline & {$[-1.946]$} & [2.828] & {$[-1.098]$} & {$[-2.996]$} & {$[2.133]$} & {$[-0.243]$} \\
\hline \multirow[t]{2}{*}{$\mathbf{U}$} & 0.009 & -0.009 & 4.116 & $0.010^{*}$ & 0.006 & -0.990 \\
\hline & {$[0.364]$} & {$[-1.103]$} & [ 1.277$]$ & [1.812] & {$[1.310]$} & {$[-1.582]$} \\
\hline R-squared & 0.979 & 0.997 & 0.648 & 0.984 & 0.979 & 0.782 \\
\hline F-statistic & 399.057 & 3455.304 & 16.115 & 528.106 & 413.608 & 31.474 \\
\hline Prob (F-statistic) & 0.000 & 0.000 & 0.000 & 0.000 & 0.000 & 0.000 \\
\hline
\end{tabular}

Notes: t-statistics in [ ]. * Significant at $5 \%$ level.** Significant at $10 \%$ level.

In both cases, the estimated coefficients of real GEP per capita in the preceding term can increases $\mathrm{CO} 2$ emissions per capita. However, the estimated coefficients of the trade are not significant in the equation of $\mathrm{LCO} 2$.

In the last step of this study, we use the variance decompositions (VDCs) and the impulse response functions because Granger causality test is strictly limited to within-sample tests and does not show the relative magnitude of these variables. So, the variance decomposition method measures the percentage of the forecast error variance of a variable that occurs as the result of a stock from each of the variables into contributions arising from its own and the other variance of the variables. Table 10 summarizes the results of variance decomposition for MATE over a 20 -year period.

In Algeria's case, the forecast error of LCO2Y is considerably explained by its own innovation by about $87 \%$ at the end of 20 years. The real GDP per capita (LY) has a weaker influence on $\mathrm{CO} 2$ emissions per capita (LCO2Y) after 20 years from the shocks. The variance of OPEN increases rapidly after 3 th year to $18^{\text {th }}$ year approximately accounted for $12 \%$ to the total variance. In the short period, the free trade measured by open can considerably effect $\mathrm{CO} 2$ emissions per capita. This result coincides with the analysis of the coefficients of VECM, Table 7.

In Tunisia's case, the variance of OPEN increases rapidly after 6th year. At the same time, GDPs share increase slowly. At the end of 20 years, the forecast error variance for $\mathrm{CO} 2$ emissions per capita explained by its own innovations is $22.83 \%$, by GDP is $5.69 \%$ and by open is $71.49 \%$. This result coincides with the analysis of the coefficients of VECM, Table 7.

In Egypt's case, the variance of OPEN increases rapidly after 3th year. At the same time, GDPs share increase slowly as in the case of Tunisia. At the end of 20 years, the forecast error variance for $\mathrm{CO} 2$ emissions per capita is considerably explained by open by more than $45 \%$ and feebly explained by GDP $(8.79 \%)$. In these three countries, OPEN considerably effects $\mathrm{CO} 2$ emission in the long-run. Furthermore, in the long-run, trade absolutely influences $\mathrm{CO} 2$ emission. 
El Alaoui, A. (2017). What is the relationship between environmental quality, economic growth and free trade? International Journal of Social Sciences and Education Research, 3(1), 124-144.

In Morocco's case, the variance of real GDP per capita and trade increase rapidly after 3th year. At the end of 20 years, the forecast error variance for $\mathrm{CO} 2$ emissions per capita is considerably explained by its own innovations by $61.56 \%$ and inconsiderably explained by GDP and open by $17.79 \%$ and $20.67 \%$ respectively.

Table 10. The results of variance decomposition for MATE of LCO2Y over a 20-year period

\begin{tabular}{|c|c|c|c|c|c|c|c|c|}
\hline & \multicolumn{4}{|c|}{ Algeria } & \multicolumn{4}{|c|}{ Tunisia } \\
\hline Period & S.E. & LCO2Y & LY & OPEN & S.E. & LCO2Y & LY & OPEN \\
\hline 1 & 0.134 & 100.00 & 0.000 & 0.000 & 0.048 & 100.00 & 0.000 & 0.000 \\
\hline 2 & 0.149 & 90.002 & 0.511 & 9.487 & 0.055 & 98.665 & 1.051 & 0.284 \\
\hline 3 & 0.154 & 88.007 & 0.482 & 11.510 & 0.060 & 97.783 & 1.400 & 0.817 \\
\hline 4 & 0.157 & 87.509 & 0.468 & 12.023 & 0.061 & 96.085 & 1.466 & 2.449 \\
\hline 5 & 0.158 & 87.342 & 0.471 & 12.188 & 0.064 & 92.132 & 1.377 & 6.491 \\
\hline 6 & 0.159 & 87.253 & 0.484 & 12.263 & 0.067 & 86.004 & 1.575 & 12.420 \\
\hline 7 & 0.159 & 87.218 & 0.510 & 12.271 & 0.070 & 79.480 & 1.811 & 18.710 \\
\hline 8 & 0.160 & 87.201 & 0.543 & 12.255 & 0.073 & 71.707 & 2.217 & 26.076 \\
\hline 9 & 0.160 & 87.189 & 0.582 & 12.230 & 0.078 & 63.912 & 2.627 & 33.461 \\
\hline 10 & 0.160 & 87.175 & 0.623 & 12.201 & 0.083 & 56.592 & 3.078 & 40.330 \\
\hline 11 & 0.161 & 87.160 & 0.668 & 12.172 & 0.088 & 50.132 & 3.500 & 46.368 \\
\hline 12 & 0.161 & 87.143 & 0.714 & 12.143 & 0.094 & 44.558 & 3.891 & 51.551 \\
\hline 13 & 0.161 & 87.125 & 0.761 & 12.114 & 0.099 & 39.851 & 4.237 & 55.912 \\
\hline 14 & 0.161 & 87.106 & 0.808 & 12.086 & 0.105 & 35.916 & 4.542 & 59.542 \\
\hline 15 & 0.162 & 87.086 & 0.856 & 12.058 & 0.112 & 32.644 & 4.807 & 62.549 \\
\hline 16 & 0.162 & 87.066 & 0.904 & 12.030 & 0.118 & 29.924 & 5.036 & 65.040 \\
\hline 17 & 0.162 & 87.045 & 0.952 & 12.003 & 0.124 & 27.659 & 5.234 & 67.107 \\
\hline 18 & 0.162 & 87.024 & 1.000 & 11.976 & 0.130 & 25.765 & 5.405 & 68.830 \\
\hline 19 & 0.162 & 87.004 & 1.047 & 11.949 & 0.136 & 24.173 & 5.554 & 70.273 \\
\hline \multirow[t]{2}{*}{20} & 0.163 & 86.983 & 1.095 & 11.922 & 0.142 & 22.827 & 5.684 & 71.490 \\
\hline & \multicolumn{4}{|c|}{ Egypt } & \multicolumn{4}{|c|}{ Morocco } \\
\hline Period & S.E. & $\mathrm{LCO} 2 \mathrm{Y}$ & LY & OPEN & S.E. & LCO2Y & LY & OPEN \\
\hline 1 & 0.060 & 100.00 & 0.000 & 0.000 & 0.046 & 100.00 & 0.000 & 0.000 \\
\hline 2 & 0.070 & 96.201 & 1.637 & 2.162 & 0.056 & 94.491 & 5.506 & 0.003 \\
\hline 3 & 0.077 & 90.108 & 3.463 & 6.429 & 0.062 & 87.984 & 10.026 & 1.989 \\
\hline 4 & 0.084 & 83.586 & 4.888 & 11.526 & 0.067 & 81.932 & 12.517 & 5.550 \\
\hline 5 & 0.090 & 77.545 & 5.902 & 16.553 & 0.071 & 77.292 & 13.869 & 8.839 \\
\hline 6 & 0.096 & 72.294 & 6.612 & 21.093 & 0.075 & 73.932 & 14.712 & 11.356 \\
\hline 7 & 0.102 & 67.857 & 7.116 & 25.027 & 0.079 & 71.459 & 15.313 & 13.229 \\
\hline 8 & 0.107 & 64.145 & 7.482 & 28.372 & 0.082 & 69.570 & 15.775 & 14.655 \\
\hline 9 & 0.112 & 61.045 & 7.755 & 31.199 & 0.084 & 68.080 & 16.144 & 15.776 \\
\hline 10 & 0.117 & 58.447 & 7.964 & 33.588 & 0.086 & 66.876 & 16.443 & 16.681 \\
\hline 11 & 0.121 & 56.258 & 8.129 & 35.614 & 0.089 & 65.885 & 16.690 & 17.425 \\
\hline 12 & 0.125 & 54.400 & 8.260 & 37.340 & 0.090 & 65.059 & 16.896 & 18.045 \\
\hline 13 & 0.129 & 52.812 & 8.368 & 38.820 & 0.092 & 64.363 & 17.070 & 18.568 \\
\hline 14 & 0.132 & 51.444 & 8.458 & 40.098 & 0.093 & 63.770 & 17.217 & 19.013 \\
\hline 15 & 0.136 & 50.259 & 8.534 & 41.207 & 0.095 & 63.262 & 17.344 & 19.394 \\
\hline 16 & 0.139 & 49.224 & 8.599 & 42.177 & 0.096 & 62.823 & 17.453 & 19.724 \\
\hline 17 & 0.141 & 48.315 & 8.655 & 43.029 & 0.097 & 62.442 & 17.548 & 20.010 \\
\hline 18 & 0.144 & 47.513 & 8.705 & 43.782 & 0.098 & 62.109 & 17.631 & 20.260 \\
\hline 19 & 0.146 & 46.800 & 8.748 & 44.452 & 0.099 & 61.817 & 17.704 & 20.479 \\
\hline 20 & 0.149 & 46.164 & 8.787 & 45.049 & 0.100 & 61.560 & 17.768 & 20.672 \\
\hline
\end{tabular}

Using the Cholesky impulse functions response, Figure 5 shows how much LCO2Y would change in response to one standard deviation of innovation to LY and OPEN in each 
El Alaoui, A. (2017). What is the relationship between environmental quality, economic growth and free trade? International Journal of Social Sciences and Education Research, 3(1), 124-144.

country. In Algeria's case, the response of innovation of LCO2Y to LY increases until period 2. After then, it drops and it is negative in the long-run. In the short-run, LCO2Y and OPEN have a negative relationship. Nevertheless, the response of LCO2Y to real GDP per capita and open are very closely. These results correspond to the previous results. In Tunisia's case, LCO2Y to LY and LCO2Y to OPEN have a very similar pattern. These three variables have negative relationships and there would be a positive response after period 3 . This is also in line with the previous results.

Both cases Egypt and Morocco, LCO2Y to LY and LCO2Y to OPEN have positive relationships after period 2. However, these patterns will be decrease after period 4 in case of Morocco. All variables have a long-run relationship.

Figure 5. Response to Cholesky One S.D. Innovations

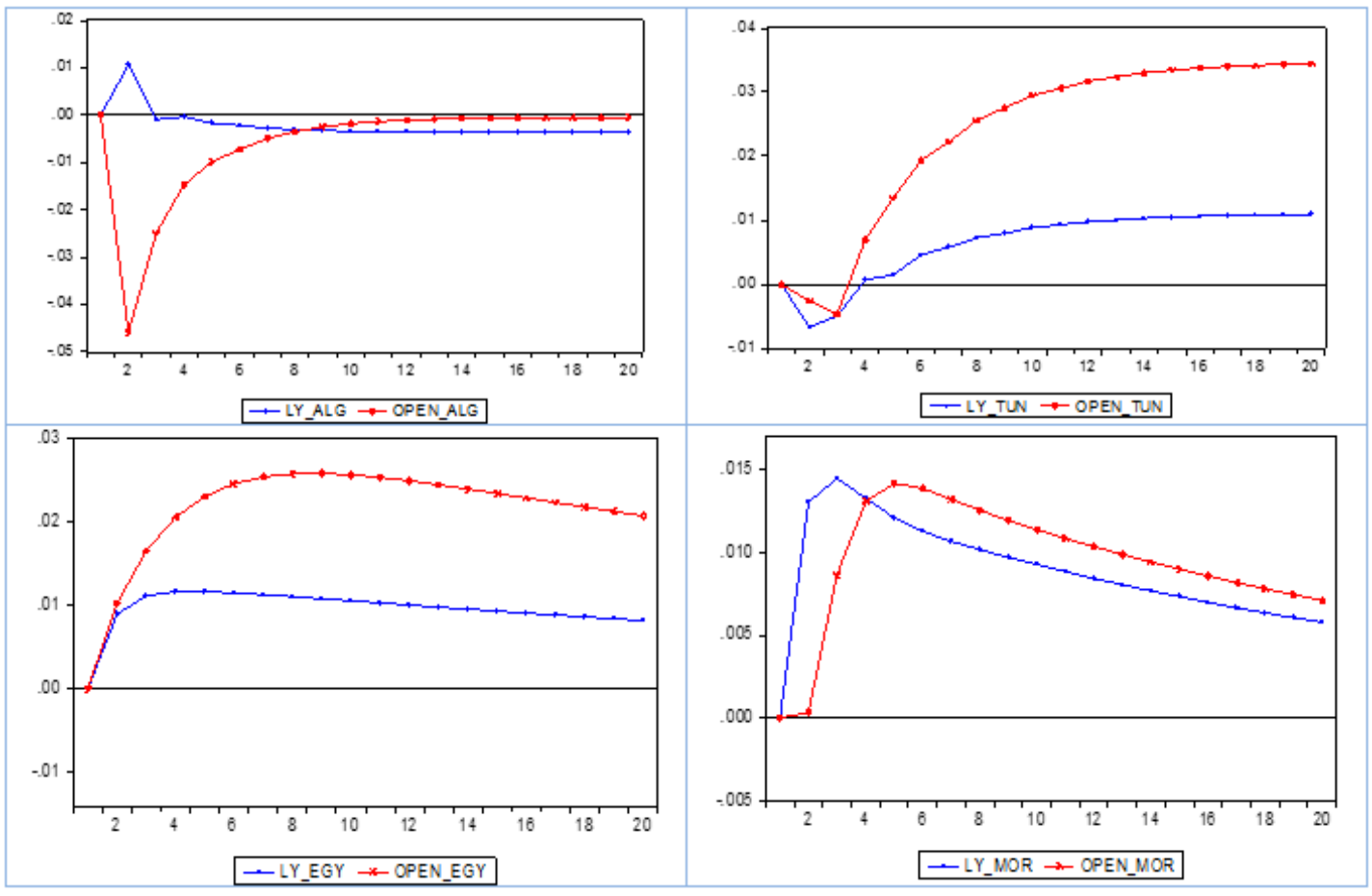

\section{Concluding remarks}

Free trade is an important component of growth for developed and developing countries. But, preserving, saving and improving the environmental quality is also an important objective to realize for all countries especially for the countries of Africa. These countries are more sensible to the global environmental changes. Currently, the primordial question is: Can the capitalism become green?

This study tried to analyze the nature of the relationship between free trade, growth and environmental quality. The main findings are that this relationship is complex and ambiguous. MATE showed very different EKC patterns and a dynamic relationship is unclear. Each country must apply adequate measures to reduce environmental damage under conditions it is important to benefit experiences of the other countries especially the developed countries 
El Alaoui, A. (2017). What is the relationship between environmental quality, economic growth and free trade? International Journal of Social Sciences and Education Research, 3(1), 124-144.

Despite there are some limitation in this study, most notable is the use of only the annual time series data on individual countries especially of the $\mathrm{CO} 2$ emissions per capita. It will be important if we use other indicators of the environmental damage. The methods used throughout this study (the OLS method, VECM, variance decomposition and impulse response functions) are given very different results between MATE. Thus, reducing $\mathrm{CO} 2$ emissions is not a straightforward solution linked with only increasing the income or improving trade because if the older pollutants are cleaned up, the new ones will emerge; thereby the environmental quality will not be reduced.

\section{References}

Antweiler, W., Copeland B. R., and Taylor M. S. (2001). "Is free trade good for the environment?", American Economic Review, 91, 877-908.

Arrow, K., B. Bolin, R. Costanza, P. Dasgupta, C. Folke, C. S. Holling, B. O. Jansson, S. Levin, K. Mäler, C. Perrings and Pimentel D. (1995). "Economic growth, carrying capacity and the environment", Science, 268, 520-21.

Bass, S. (2006). "Making poverty reduction irreversible: development implications of the Millennium Ecosystem Assessment". IIED Environment for the MDGs' Briefing Paper. International Institute on Environment and Development, London

Becker, G. S., (1962). "Investment in Human Capital: A Theoretical Analysis". Journal of Political Economy, 70(5): pp. 9-19.

Beckerman, W. (1992). "Economic development and the Environment: Conflit or Complementarity", Background Paper for the World Development Report 1992, The World Bank, Washington, DC.

Blaug, M., (1976). "The Empirical Status of Human Capital Theory: A Slightly Jaundiced Survey". Journal of Economic Literature, 14(3): 827-55.

Bourdieu, P., (1985). "The forms of capital". In JG Richardson (Ed.), Handbook of Theory and Research for the Sociology of Education, pp. 241-258. NewYork: Greenwood.

Bradford D.F., R. Schlieckert and S.H. Shore (2005), "The Environmental Kuznets Curve: Exploring a Fresh Specification", Economic Analysis \& Policy 4(1), Article5.

Chertow, M. R. (2001). "The IPAT Equation and Its Variants. Changing Views of Technology and Environmental Impact". Journal of Industrial Ecology, Vol. 4. No4. pp. 13-29.

Chivian E, Bernstein A. (2010). "How Our Health Depends on Biodiversity". Boston, MA: Center of Health and the Global Environment, Harvard Medical School.

Cole, M. A., Rayner A. J. and Bates J. M. (1997). "The Environmental Kuznets Curve: An Empirical Analysis", Environment and Development Economics, vol. 2; pp. 401-416.

Cole, M. A. (1999). "Limits to growth, Sustainable development and Environmental Kuznets Curves: an Examination of the environmental impact of economic development", Sustainable Development. Sust. Dev. 7, 87-97.

Cole, M. A. and Neumayer, E. (2005). "Environmental policy and the environmental kuznets curve: can developing countries escape the detrimental consequences of economic growth?". In: Dauvergne, Peter, (ed.) Handbook of Global Environmental Politics. Elgar original reference. Edward Elgar, Cheltenham, UK, 298-318. ISBN 9781843764663

Coleman, J. S., (1988a). "Social capital in the creation of human capital". Am. J. Social, 94: 95-121. 
El Alaoui, A. (2017). What is the relationship between environmental quality, economic growth and free trade? International Journal of Social Sciences and Education Research, 3(1), 124-144.

Coleman, J. S., (1988b). "The creation and destruction of social capital: implications for the law". Notre Dame J. Law, Ethics, Public Policy, 3: 375-404.

Commoner, B., Corr, M., and Stamler, P. J., (1971). "The Causes of Pollution". Environment 13: 2-19.

Commoner, B. (1972. a). "A Bulletin Dialogue on 'The Closing Circle': Response". Bulletin of the Atomic Scientists 28 (5): 17, 42-56.

Commoner, B. (1972. b). "The Environmental Cost of Economic Growth". pp. 339-363 in R. G. Ridker (ed.). Population, Resources and the Environment. Washington, DC: Government Printing Office.

Costanza, R and DalyH. E., (1992). "Natural capital and Sustainable development". Conserve. Biol., 6: $37-46$.

Cropper, M. and Griffiths, C. (1994). "The Interaction of Population Growth and Environmental Quality". The American Economic Review. Vol. 84, No. 2, Papers and Proceedings of the Hundred and Sixth Annual Meeting of the American Economic Association (May, 1994), pp. 250-254

Daniel J. Jacob. (1999). "Introduction to atmospheric chemistry". Published by Princeton University Press Princeton, New Jersey.

Ehrlich, P. R. and Holdren, J. P. (1971). "Impact of Population Growth. " Science 171: 1212-1217.

Ehrlich, P. R. and Holdren, J. P. (1972). "A Bulletin Dialogue on 'The Closing Circle': Critique. " Bulletin of the Atomic Scientists 28(5): 16, 18-27.

Ekins, P. (1997). "The Kuznets curve for the environment and economic growth: examining the evidence", Environment and Planning A, 29, 805-30.

El Alaoui, A. (2015). "Causality and Cointegration between Export, Import and Economic Growth: Evidence from Morocco", Journal of World Economic Research 2015; 4(3): 83-91. doi: 10.11648/j.jwer.20150403.14

El Alaoui, A. and Nekrach, H. (2015). "For sustainable economic growth that seeks improving environmental quality: an empirical analysis applied to Morocco, Algeria, Tunisia, and Egypt", Communication on 4th Edition of the EHSP-NRCS International Conference on: Human \& Environmental Security in the Era of Global Risks (HES2015). November 25-27, 2015 | Agadir, Morocco

Galeotti M. and A. Lanza (1999). "Richer and cleaner? A study on carbon dioxide emissions in developing countries", Energy Policy 27, 565- 573.

Global Development Research Center (GDRC), "SD Features Sustainability Concepts: Natural capital", www. gdrc. org/sustdev/concepts/26-nat-capital. html

Grossman, G. M., \& Krueger, A. B. (1991). "Environmental impacts of a North American Free Trade Agreement". National Bureau of Economic Research. Working Paper No 3914, NBER, Cambridge MA.

Grossman, G. M. and Krueger, A. B. (1995). "Economic growth and the environment", Quarterly Journal of Economics Vol.112, pp. 353-378.

IPCC, Intergovernmental Panel on Climate Change, (2014). "Climate Change 2014: Synthesis Report". Contribution of Working Groups I, II and III to the Fifth Assessment Report of the Intergovernmental Panel on Climate Change [Core Writing Team, R. K. Pachauri and L. A. Meyer (eds.)]. IPCC, Geneva, Switzerland, 151 page.

Khagram, S., Clark, W. C., and Raad, D. F. (2003). "From the Environment and Human Security to Sustainable Security and Development", Journal of Human Development 4(2): 289-313. 
El Alaoui, A. (2017). What is the relationship between environmental quality, economic growth and free trade? International Journal of Social Sciences and Education Research, 3(1), 124-144.

Kiker, B. F., (1966). "The historical roots of the concept of human capital", Journal of Political Economy, 74(5): 481-99.

Kuznets, S. (1955). "Economic growth and income inequality", American Economic Review, 49, 128.

List J.A. and C.A. Gallet (1999). "The environmental Kuznets curve: does one size fit all? ", Ecological Economics 31, 409-423.

Lopez, R. (1994). "The Environment as a Factor of Production: The Effects of Economic Growth and Trade Liberalization". Journal of Environmental Economics and Management 27(2): 185-204.

Martino, D. and Zommers, Z. (2007). "Environment for Development", Chapter 1 of report of Global Environment Outlook, GEO4, United Nations Environment Programme (UNEP).

Mincer, J., (1958). "Investment in human capital and personal income distribution", Journal of Political Economy, 66(4): 281-302.

Mincer, J., (1962). "On-the-job training: Costs, returns, and some implications", Journal of Political Economy, 70: 50-79.

O'Connor, D., (1994). Managing the Environment with Rapid Industrialisation: Lessons from the East Asian Experience. Development Centre Study, OECD, Paris

Panayotou, T. (1993). "Empirical tests and policy analysis of environmental degradation at different stages of economic development". Working Paper WP238, Technology and Employment Programme, International Labour Office, Geneva.

Panayotou, T. (1997). "Demystifying the Environmental Kuznets Curve. Turning a Black Box into a Policy Tool", Environment and Development Economics. Vol.2, Issue:4, pp 465-484.

Panayotou, T. (2003). "Economic growth and the environment", Harvard University and Cyprus International Institute of Management.

Perman, R. and Stern, D. I. (1999). "The environmental Kuznets curve: implications of Nonstationarity", working papers in ecological economics 9901, Centre for Resource and Environmental Studies, Australian National University, Canberra.

Portes, A., (1998). "Social capital: its origins and applications in modern sociology". Annual Review of Sociology, 24: 1-24.

Putnam, R. D., (1993). "The prosperous community: social capital and public life". American Prospect, 4(13): 35-42.

Selden, T. M. and Song D. (1994). "Environmental Quality and Development: Is There a Kuznets Curve for Air Pollution Emissions?", Journal of Environmental Economics and Management, vol.27; pp. 147-162.

Shafik, N., and Bandyopadhyay, S. (1992). "Economic Growth and Environmental Quality: Time Series and Crosscountry Evidence". Background Paper for the World Development Report 1992, the World Bank, Washington, DC.

Shafik, Nemat. 1994. Economic Development and Environmental Quality: An Econometric Analysis. Oxford Economic Papers 46: 757-77.

Schultz, T. W., (1961). "Investment in human capital", The American Economic Review, 51(1): 1-17.

Schultz, T. W., (1962). "Reflexions on investment in man", Journal of Political Economy, 70(5): 1-8.

Stern, D. I. and Common M. S. (2001). "Is there an environmental Kuznets curve for sulfur?", Journal of Environmental Economics and Management, 41, 162-78. 
El Alaoui, A. (2017). What is the relationship between environmental quality, economic growth and free trade? International Journal of Social Sciences and Education Research, 3(1), 124-144.

Stern David I. (2004). "The Rise and Fall of the Environmental Kuznets Curve", World Development Vol. 32, No.8, pp. 1419-1439.

Torras, M. and Boyce J. K. (1998). "Income, Inequality, and Pollution: A Reassessment of the Environmental Kuznets Curve". Ecological Economics 25(2): 147-60.

World Bank (2006). "Where is the Wealth of Nations? Measuring Capital for the 21st Century". The World Bank, Washington, DC

Yandle B., Vijayaraghavan, M. and Bhattarai, M. (2002). "The Environmental Kuznets Curve: A Primer". Research Study 02-1. Montana, USA. Political Economy Research Center (PERC). 